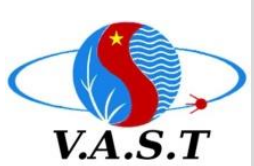

Vietnam Academy of Science and Technology

Vietnam Journal of Earth Sciences

http://www.vjs.ac.vn/index.php/jse

\title{
Paleomagnetism of Permian-Triassic volcanic sequences from Son La province, northwest Vietnam
}

\author{
Cung Thuong Chi ${ }^{*}$, John W. Geissman², Taylor Borgfeldt 3 , Nguyen Hoang ${ }^{1}$ \\ ${ }^{1}$ Institute of Geological Sciences, VAST, Hanoi, Vietnam \\ ${ }^{2}$ Department of Geosciences, University of Texas at Dallas, ROC 21, 800 West Campbell Road, \\ Richardson, Texas 75080-3021, USA \\ ${ }^{3}$ Jackson School of Geosciences, University of Texas at Austin Department of Geosciences, Austin, TX \\ 78759, USA
}

Received 26 September 2020; Received in revised form 7 February 2020; Accepted 11 March 2021

\begin{abstract}
Nineteen sites with 198 oriented-core samples have been collected from the Upper Permian-Lower Triassic volcanic rocks of Vien Nam Formation at Quynh Nhai locality, Son La Province, northwestern Vietnam. The characteristic remanent magnetization components carried by magnetite and hematite were successfully isolated from secondary components reveal a mean paleomagnetic direction Ds $=48.3^{\circ}, \mathrm{Is}=-10.0^{\circ}, \alpha_{95}=8.0^{\circ}$, corresponding to a virtual geomagnetic pole located at $\lambda=35.7^{\circ} \mathrm{N}, \phi=217.4^{\circ} \mathrm{E}$ and a paleo-latitude of study area situated at $5.1^{\circ} \mathrm{S}$ during the Permian time. Compared with the Late Permian-Early Triassic pole of the South China Block (SCB), the data show that crustal elements of NW Vietnam have been close to, but not unequivocally a coherent part of the SCB, since the Late Permian. Development of the parallel NW-SE striking Song Ma and Song Chay orogenic belts did not involve the closure of wide $(>500 \mathrm{~km})$ ocean basins.
\end{abstract}

Key words: Paleomagnetism; characteristic remanent magnetization; virtual geomagnetic pole; paleo-latitude; volcanic rocks.

C2021 Vietnam Academy of Science and Technology

\section{Introduction}

The Mesozoic dispersal of the Gondwana continents and closure of Paleo-, Meso- and Neo-Tethys involved the accretion of numerous continental fragments to southern Eurasia with attending magmatism. Accurate paleo-latitude and paleo-orientation information on these fragments that now comprise Indochina are required to better understand their original configuration

*Corresponding author, Email: chicung@gmail.com relative to the South China block and timing and style of deformation associated with the Indochina block.

On the basis of biogeographic and paleomagnetic data, paleogeographic reconstruction models of Permian eastern Pangea and Tethys have been proposed by different workers (Sengor; 1979; 1984; 1987; 1989; Hutchison, 1989; Gatinsky and Hutchison, 1986; Metcalfe, 1988; 1991; 1996; 2002; 2011; Scotese et al., 1992; 1995; Dercourt et al., 1993; Ziegler et al., 1997; 
Zonenshain et al., 1985; Li et al., 1993; Li and models broadly agree on the reconstruction of Powell, 2001). All of the reconstruction the principal components of Pangea (Fig. 1).
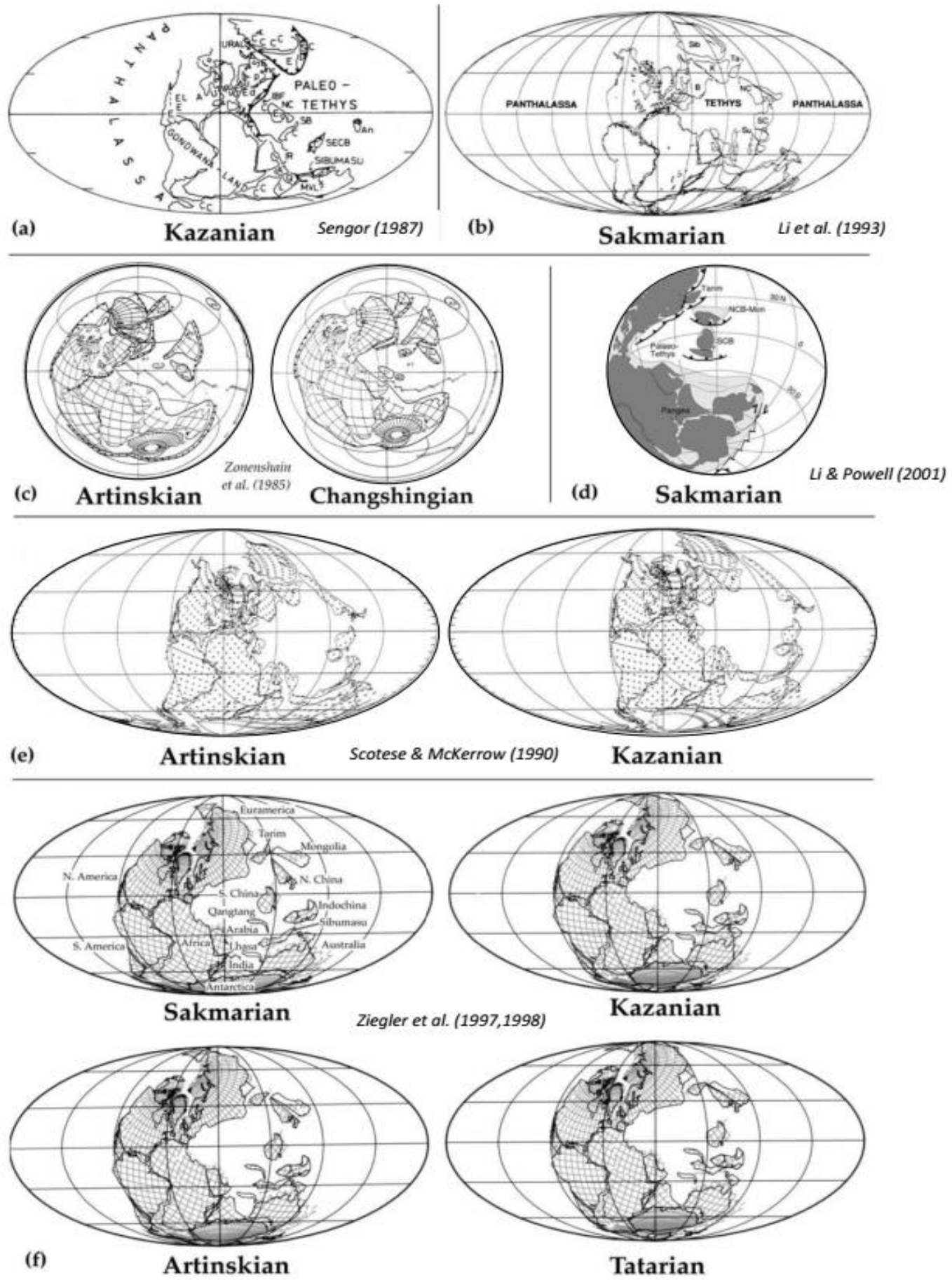

Figure 1. Paleogeographic reconstruction models of Permian eastern Pangea and Tethys (Modified from Metcalfe, 2002) 
Most models for the position of South China during the Permian have the subcontinent situated on, or slightly south of the equator and slightly counter-clockwise rotated; this configuration has been supported by paleomagnetic, biogeographic and climatic data and it did not experience significant latitudinal displacement during the Permian. The position of the Indochina block, however, is somewhat in dispute. Scotese and McKerrow (1990) and Metcalfe $(1998 ; 2002)$ and $\mathrm{Li}$ and Powell (2001) position Indochina and South China together, welded along the Song Ma Suture Zone during Late DevonianEarly Carboniferous and forming the South China- Indochina Super-terrane during the Permian, characterized by Tethyan fauna and Cathaysian flora (Hutchinson, 1989; Metcalfe, 2002). Ziegler et al. (1997; 1998), on the other hand, argue that these terranes remain separated during the Permian.

We have initiated a collection of wellexposed sequences of Upper Permian-Lower Triassic volcanic rocks exposed near the Song Da lineament in northwest Vietnam. In this paper, we report the new paleomagnetic results of Upper Permian-Lower Triassic volcanic formations from Quynh Nhai locality, Son La Province in northwestern Vietnam.

\section{Geologic-tectonic setting and sampling area}

Upper Permian-Lower Triassic volcanic rocks are widely exposed in northwest Vietnam, mainly within the Song Da rift basin located NE of the Song Ma Suture Zone that forms the boundary between the South China Block and the Indochina Block. Permian basalts within the Song Da rift are considered distal equivalents of the Emeishan rift basalts; the geochemistry of these basalts and associated Permian-Triassic komatiites suggests a plume related source (Hanski et al., 2004; Zhou et al., 2008). On the other hand, Lepvrier et al. (2004; 2008) suggest that the Permian basalts exposed north of the Song Ma Suture Zone (within Song Da rift basin) could have been emplaced in a back-arc continental setting due to a north-dipping oceanic subduction system of Indochina beneath South China, yet an inferred calc-alkaline magmatic arc of that age is not well documented. Some authors suggest that Indochina and South China were separated by oceanic crust in the Late Permian to EarlyMiddle Triassic and that they collided during the Indosinian Orogeny in the Late Triassic (Zhang et al., 2006; Zhang and Cai, 2009; Cai and Zhang, 2009).

Permian flood basalts and associated mafic-ultramafic intrusions form a narrow NW-trending belt in the Song Da rift terrane. The belt is bounded by the Red River fault zone to the northeast and the Song Ma suture to the southwest (Fig. 2).

The flood basalts unconformably overlie the early Permian limestones and are concordantly overlain by the early Triassic limestone and shale (Glotov et al., 2001). Folded Triassic sedimentary rocks are unconformably overlain by Cretaceous conglomerates, sandstones and pelites (Lacassin et al., 1998).

Upper Permian - Lower Triassic volcanic rocks in the Song Da rift terrane have been divided into the Cam Thuy and Vien Nam formations. The Upper Permian Cam Thuy Formation consists of mafic extrusive rocks of tholeiitic affinity that are widely exposed in the southeast part of the Song Ma anticline within Thanh Hoa, Ninh Binh, and Hoa Binh, Son La to the north of Song Ma suture. The volcanic rocks of the Cam Thuy Formation are, in general, basalt, basaltic andesite, or andesite and are up to $1000 \mathrm{~m}$ thick (Hoa Binh area). They are dominated by high magnesium, low titanium and alkaline basalt, equivalent to tholeiite series rocks (Polyakov et al., 1999; Tran Trong Hoa, 2001).

The Vien Nam Formation (Phan $\mathrm{Cu}$ Tien, 1977) is widely distributed within the Song $\mathrm{Da}$ rift terrane, from the Vien Nam area - Ba Vi extending through Kim Boi (Hoa Binh) to 
Van Yen, Ta Khoa and Nam So (Son La) areas in northwest Vietnam. Tran Trong Hoa (2001) describes the extrusive rocks of Vien Nam Formation as belonging to a combination of basalt (trachybasalt) - trachyandesite trachydacite, which are sub-alkaline basalts with high $\mathrm{Ti}$ and high alkaline compositions. Based on isotopic age determinations
(Polyakov et al., 1999; Tran Trong Hoa, 1996; Hanski et al., 2004), the interpreted age of the basaltic rocks is between about $257 \pm 24 \mathrm{Ma}$ and $270 \pm 15 \mathrm{Ma}$, corresponding to the Late Permian-Early Triassic, and is inferred to be coeval with the Emeishan basalts exposed in South China.

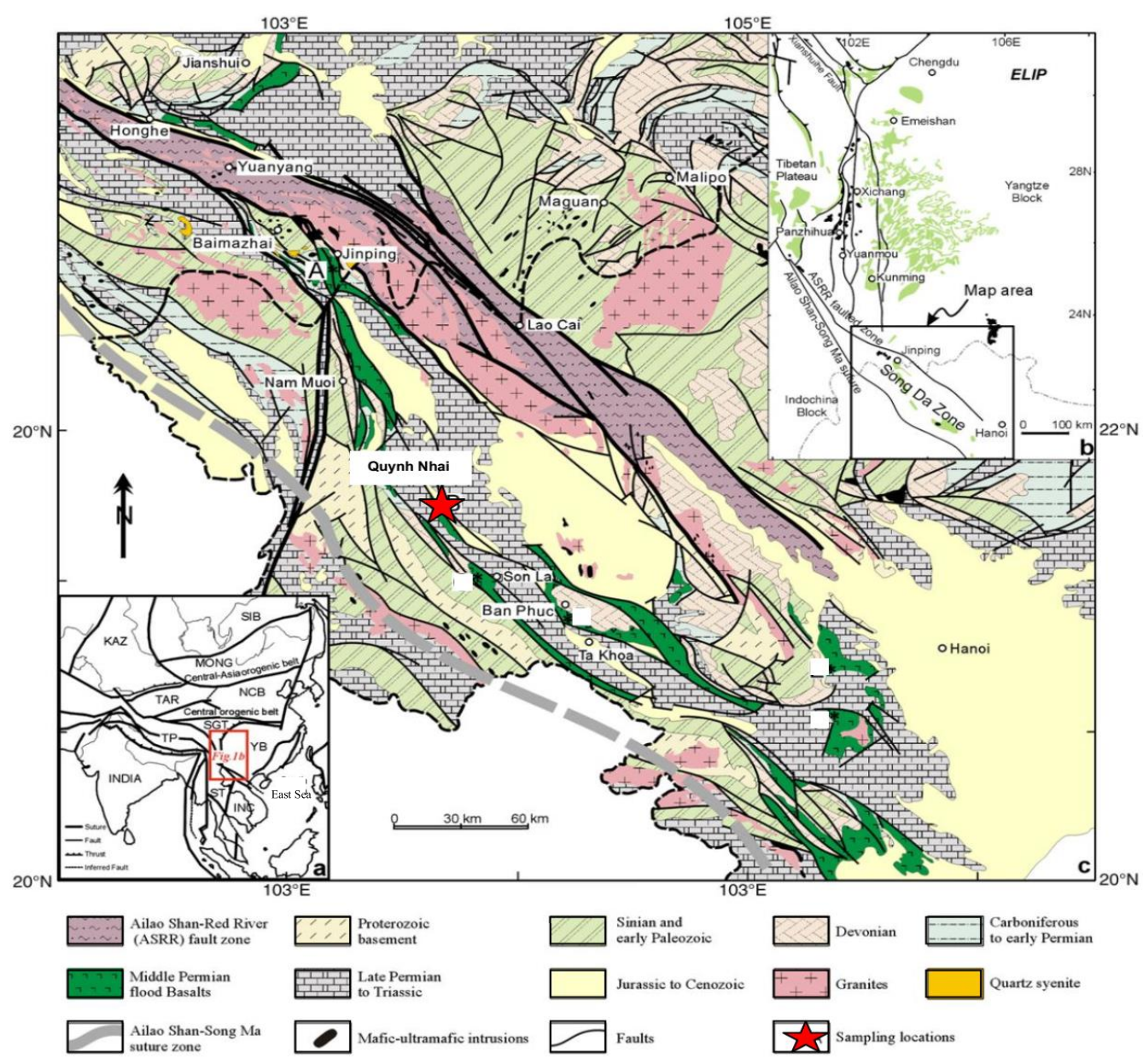

Figure 2. Geological sketch map of the NW Vietnam region showing the study area, modified from Wang et al. (2007). The major blocks shown in inset (a) are: SIB, Siberia; MONG, Mongolia; NCB, North China Block; YB, Yangtze Block; INC, Indochina Block; TAR, Tarim; KAZ, Kazakhstan; TP, Tibet Plateau; SGT, Songpan-Ganze terrane. The Emeishan Large Igneous Province in SW China and northern Vietnam is shown in inset (b)

At Quynh Nhai locality, there are several outcrops of vesicular basalt and basaltic andesite of Vien Nam Formation on the road from Quynh Nhai town to the Pa Uon Bridge crossing the Da River. These basalts had been periodically emplaced at the surface revealed by at least $8-10$ flows of $\sim 0.5 \mathrm{~m}$ in thickness with flow orientations varying from 192- 
$218^{\circ} / 44-79^{\circ} \mathrm{SW}$ that enables to have a reliable Nineteen sites with 198 oriented-core samples tectonic control for these basalts (Fig. 3). have been collected from these outcrops.

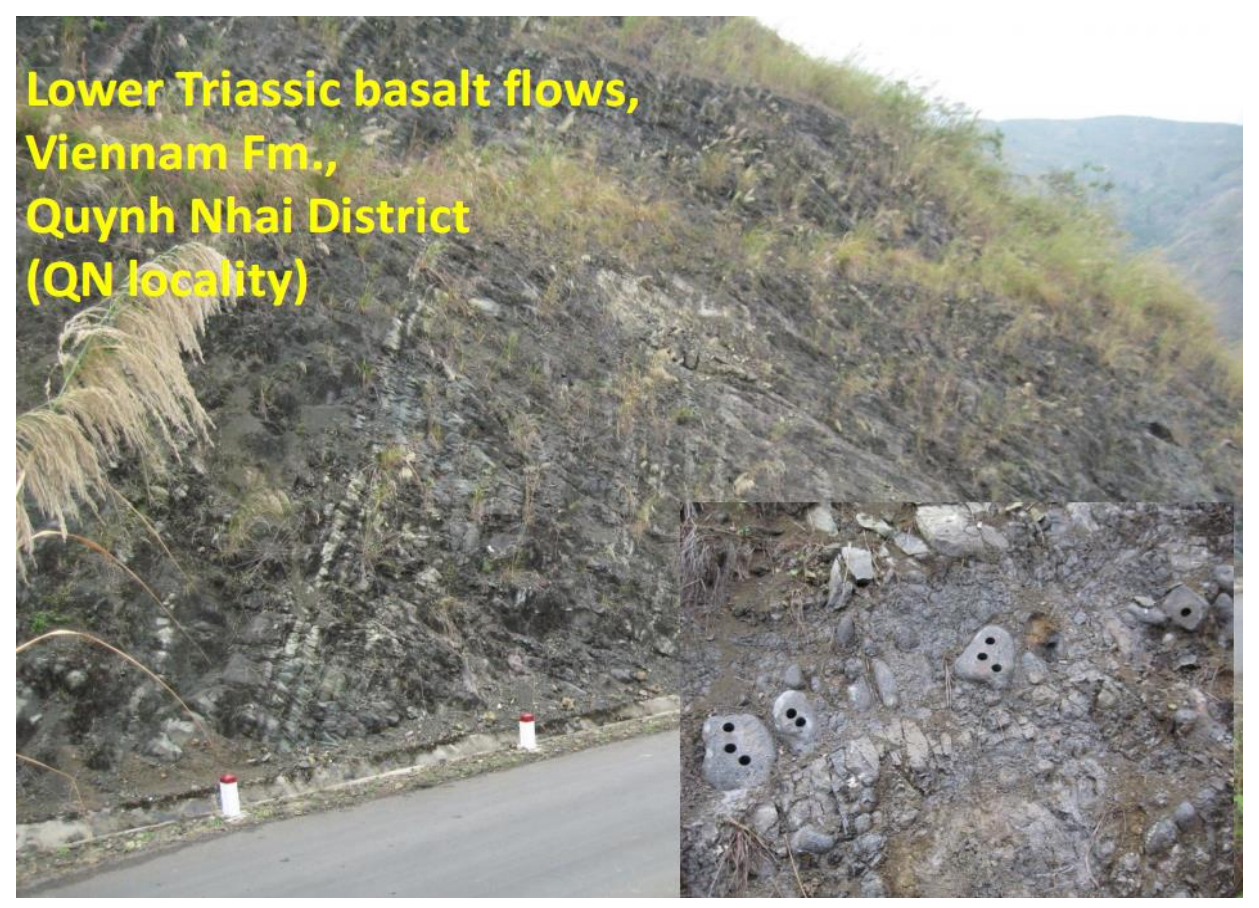

Figure 3. Photo showing the outcrop of the lower Triassic basalt flows of the Vien Nam formation at Quynh Nhai locality, Son La, NW Vietnam

\section{Rock magnetism}

Individual specimens of $25 \mathrm{~mm}$ in diameter and $22 \mathrm{~mm}$ in length have been prepared from each sample in the laboratory. Natural remanent magnetizations (NRMs) were measured by $2-G$ Enterprise's cryogenic magnetometer. One specimen from each sample was subjected to stepwise thermal demagnetization up to $690^{\circ} \mathrm{C}$ using a TDS- 1 thermal demagnetizer with a residual field of less than $5 \mathrm{nT}$. Demagnetization results for each specimen were plotted on orthogonal vector diagrams (Zijderveld, 1967) to assess the component structure as well as on equalarea projections to evaluate directional stability. Principal component analysis (Kirschvink, 1980) was used to estimate component's directions. Site-mean directions were calculated using Fisherian statistics (Fisher, 1953). The natural remanent magnetizations of basaltic rocks are rather strong, ranging from $15.8 \mathrm{~mA} / \mathrm{m}$ to $3.78 \mathrm{~A} / \mathrm{m}$, and consist of two or more components (Figs. $4,5)$. These rocks show excellent response in the progressive alternating field and/or thermal demagnetization. For any single section sampled, there is a mix of carriers of the characteristic remanent magnetization (ChRM), with some flows having low $\mathrm{Ti}$ magnetite as the principal carrier of the ChRM and other flows having hematite as the ChRM. The experiments of rock's magnetic susceptibility during the heating and cooling processes shown in Fig. 6 also revealing the behavior of ChRM multi-components. The magnetic minerals in the rock structure are shown in Fig. 7. Rock magnetic data and petrography support the retention of an earlyacquired thermo-remanent magnetization; anisotropy of magnetic susceptibility (AMS) data is not consistent with a pervasive postemplacement deformation fabric (Fig. 8). 
Vietnam Journal of Earth Sciences, 43(2), 220-235
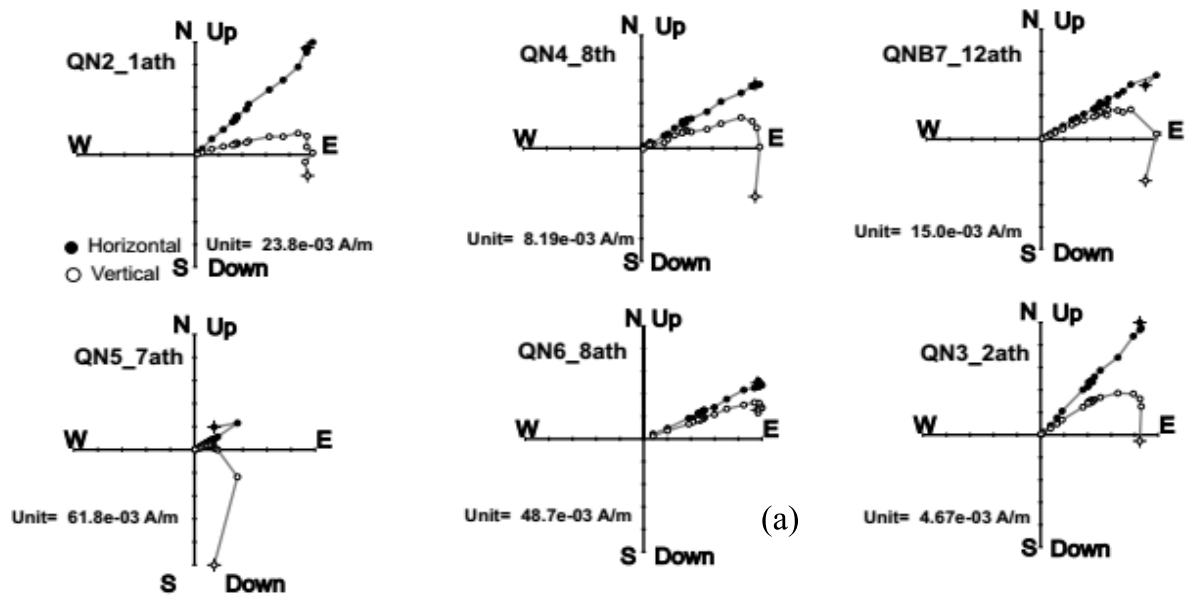

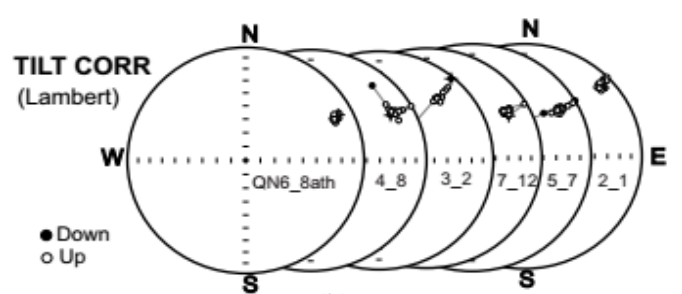

(b)

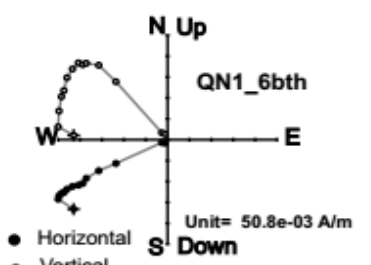

- Vertical
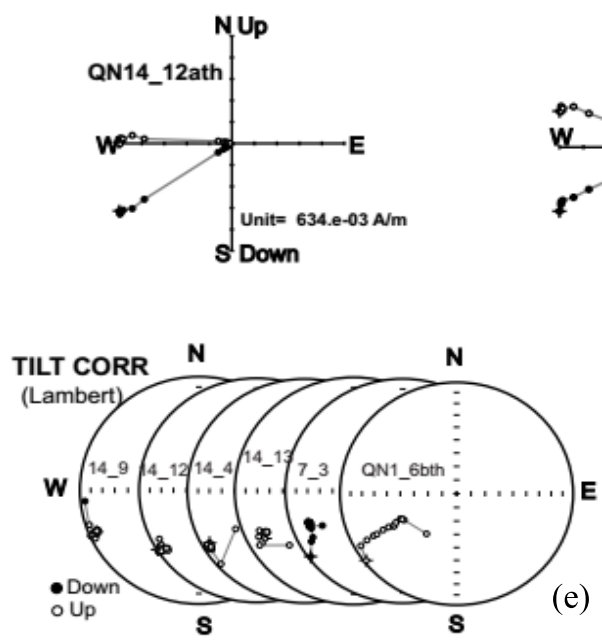

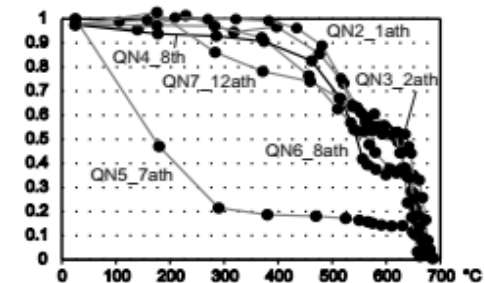

(c)
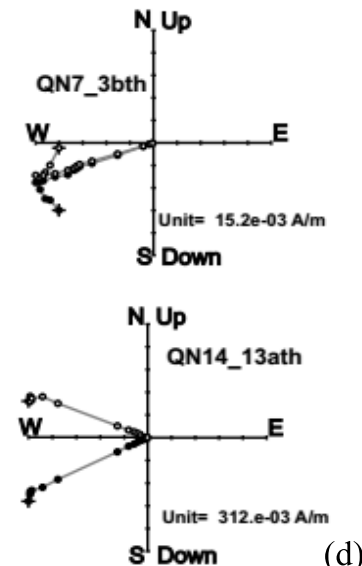

d)
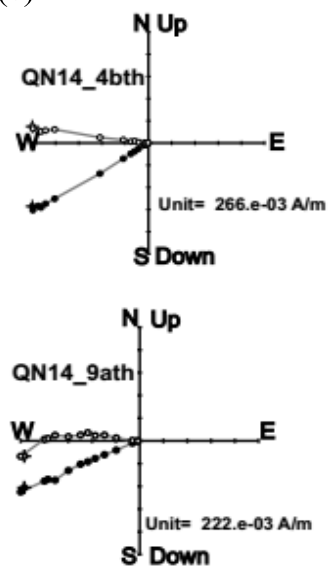

Figure 4. Representative thermal demagnetization plots of rock specimens; (a) \& (d): Zijderveld plots, (b) \& (e): Lambert equal-area plots, (c) \& (f): normalized NRM plots 
Vietnam Journal of Earth Sciences, 43(2), 220-235
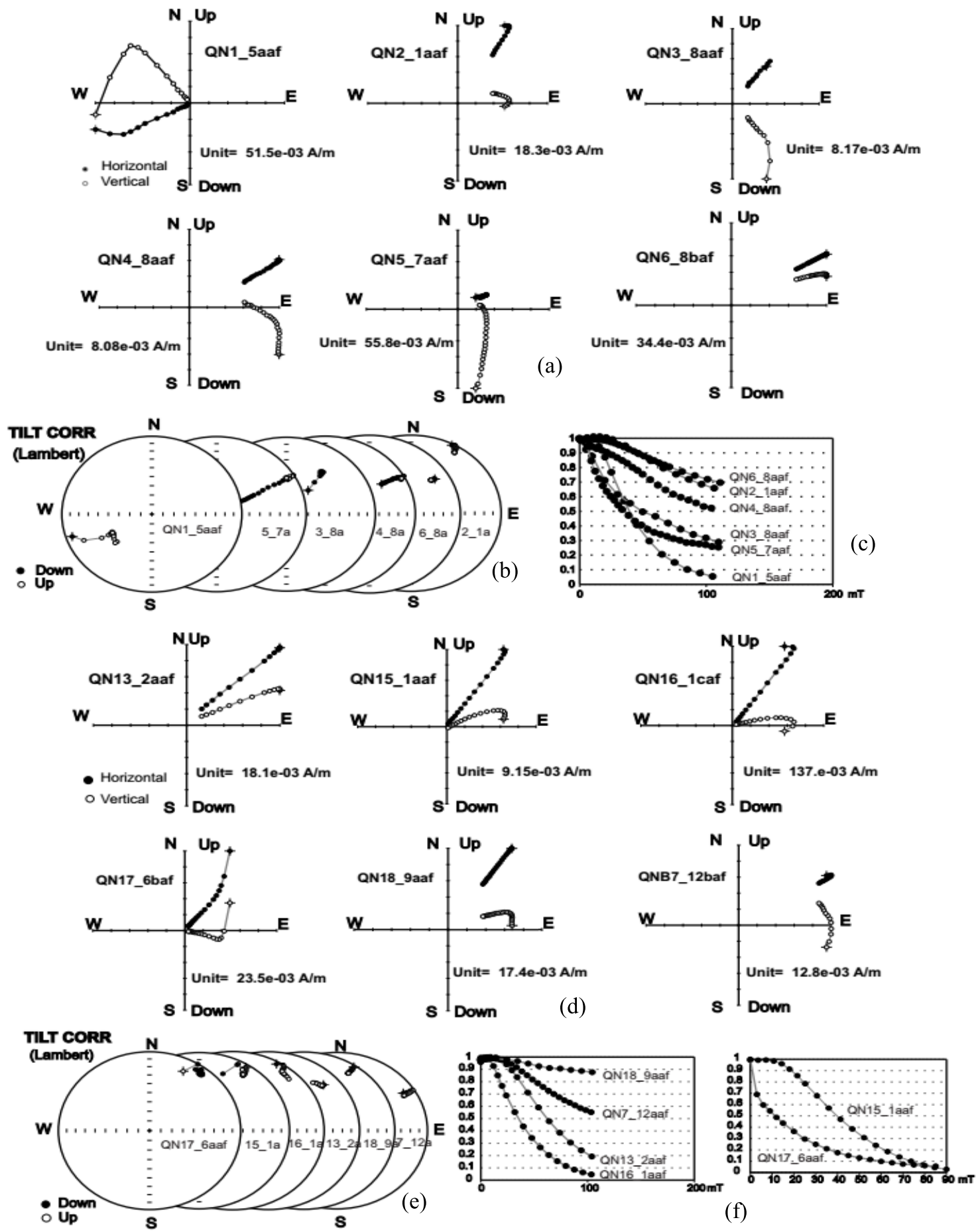

(f)

Figure 5. Representative AF demagnetization plots of rock specimens; (a) \& (d): Zijderveld plots, (b) \& (e): Lambert equal-area plots, (c) \& (f): normalized NRM plots 
Cung Thuong Chi et al./Vietnam Journal of Earth Sciences 43(2021)
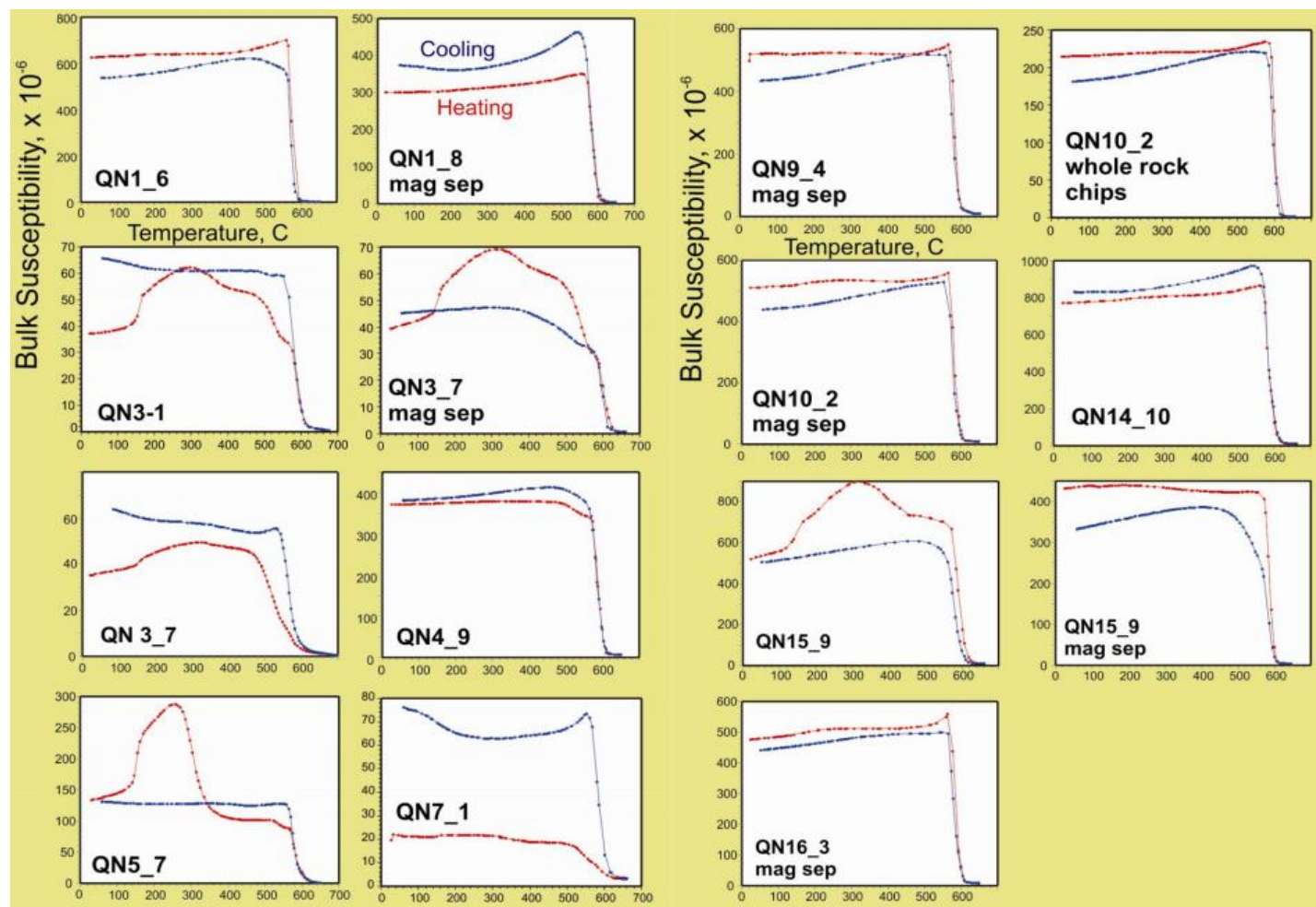

Figure 6. Bulk magnetic susceptibility of representative rock specimens during heating and cooling process showing the behavior of ChRM multi-components of low Ti magnetite and hematite

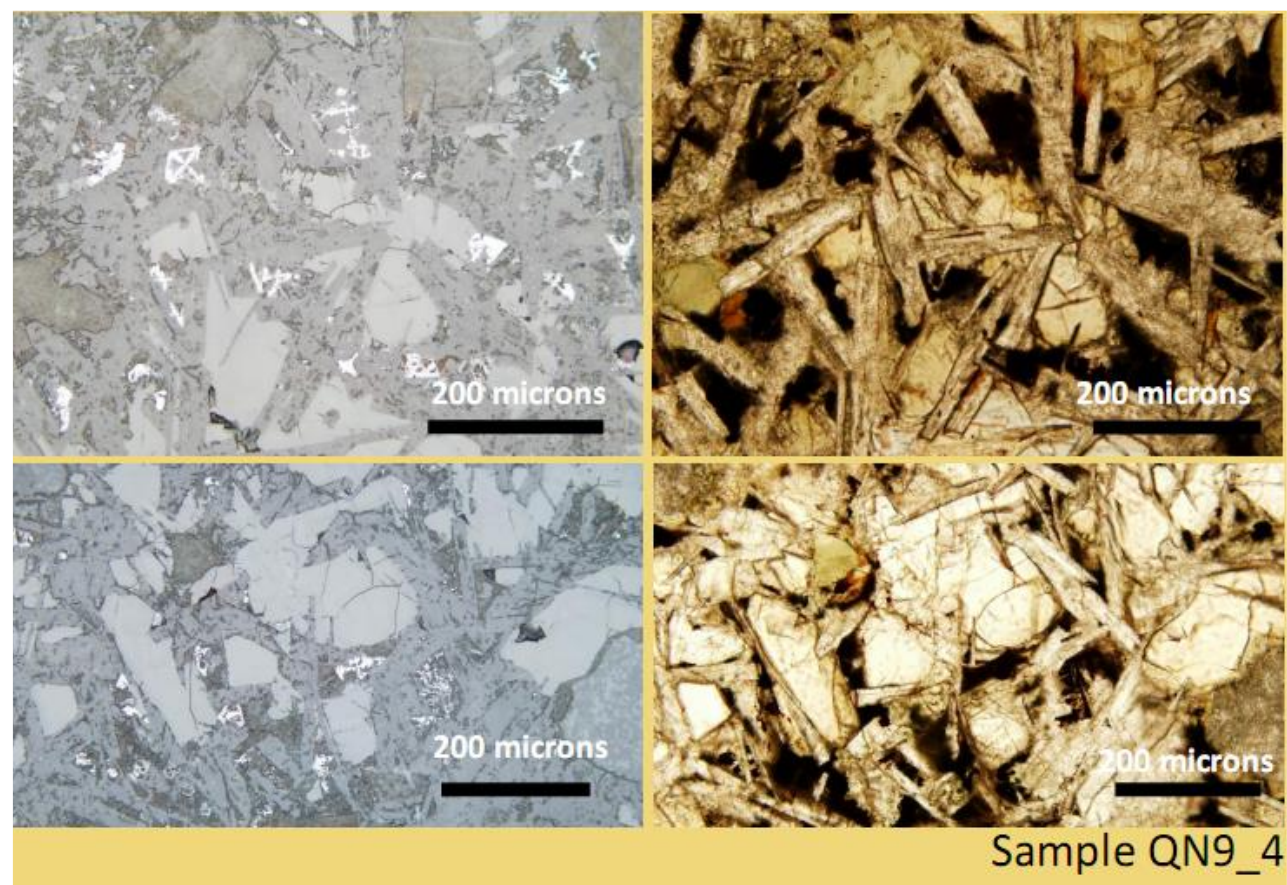

Figure 7. Microscopic photos show the structure of magnetic-bearer minerals 


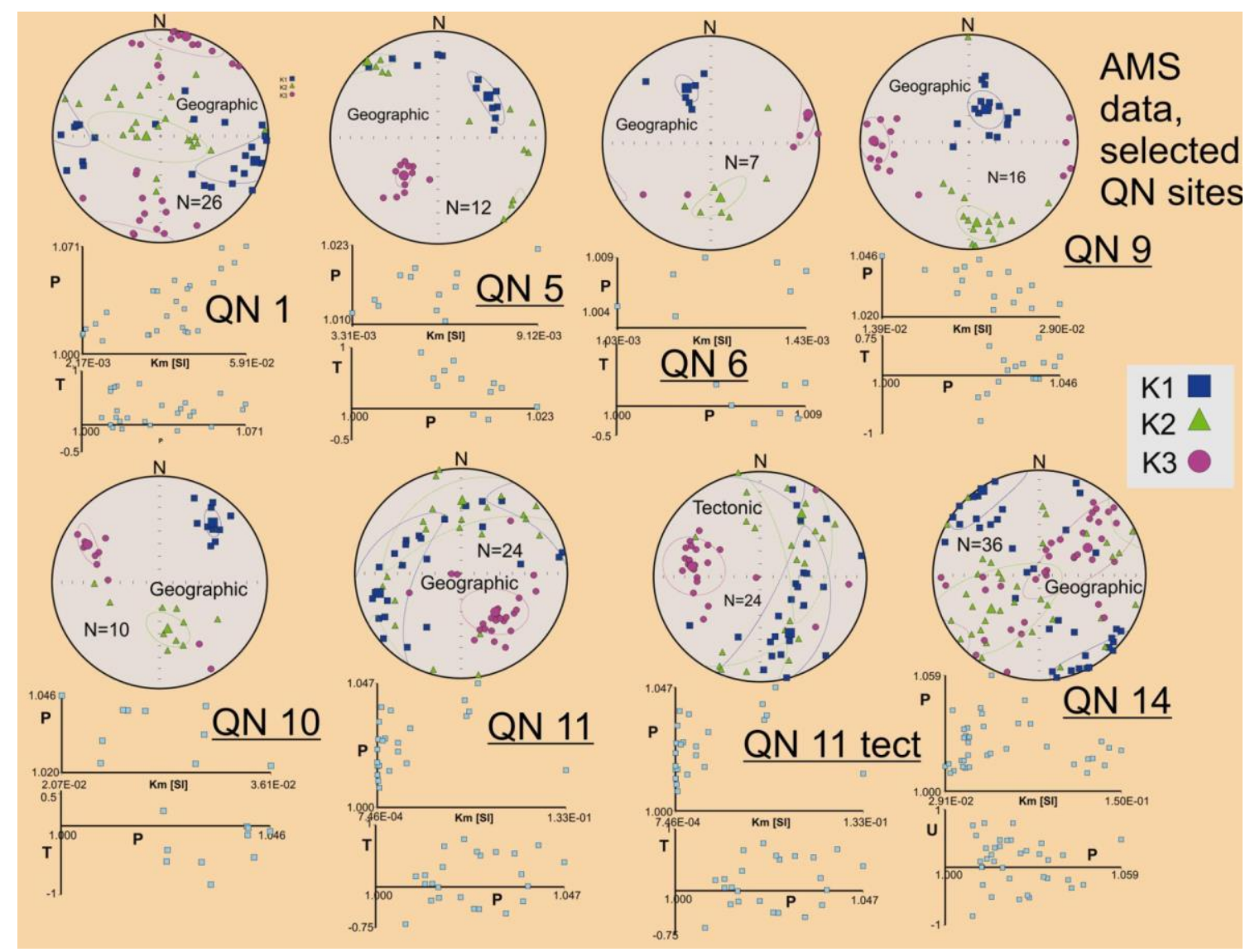

Figure 8. Anisotropy of magnetic susceptibility (AMS) of selected samples

\section{Paleomagnetic results}

The site-mean directions of ChRM components are plotted on the Lambert equalarea projection (Fig. 9) and their values are listed in Table 1. At the site level, magnetization directions are consistent and estimates of mean directions have $95 \%$ confidence estimates of less than $7^{\circ}$. Preliminary between-site data suggest that a reasonable magnitude of paleosecular variation has been recorded. In situ estimated site mean directions do not resemble predicted time-averaged geomagnetic field directions for the study area for Triassic and younger time, using paleomagnetic poles from the South China Block and therefore we argue that these volcanic sections have not been pervasively remagnetized. Magnetizations are of dual polarity with inclinations generally less than $20^{\circ}$.

The formation mean direction of 13 sites yields the values $D_{\mathrm{s}}=48.3^{\circ}, \mathrm{I}_{\mathrm{s}}=-10.0^{\circ}, \alpha_{95}=$ $8.0^{\circ}, \mathrm{k}=27.7\left(\mathrm{k}_{\mathrm{s}} / \mathrm{k}_{\mathrm{g}}=1.37\right)$; corresponding to a virtual geomagnetic pole (VGP) located at $\lambda$ $=35.7^{\circ} \mathrm{N}, \phi=217.4^{\circ} \mathrm{E}$. The paleopole position of Quynh Nhai basaltic rocks is basically indistinguishable from the paleopole of Late Permian-Early Triassic paleopole for the South China Block (Fig. 10). The similar paleopole positions of two distal basaltic rock formations from NW Vietnam and South China further corroborate the hypothesis of coeval time emplacement and originated from the same source for these formations. The 
paleolatitude of the study area calculated from the formation mean direction is $\lambda_{\mathrm{obs}}=-5.1^{\circ} \mathrm{N}$ (or $5.3^{\circ} \mathrm{S}$ ) indicating that the Quynh Nhai basaltic rock formation was emplaced on the Earth during the Late Permian-Early Triassic time near the equatorial region.
Using the mean paleopole of Upper Permian - Early Triassic volcanic rock formations from South China Block (Table 2), the expected paleomagnetic direction of Quynh Nhai locality is computed and has the values: $\mathrm{D}_{\mathrm{ex}}=33.6^{\circ}, \mathrm{I}_{\mathrm{ex}}=-10.3^{\circ}, \lambda_{\mathrm{ex}}=-5.2^{\circ} \mathrm{N}$.

Table 1. Paleomagnetic results of Late Permian-Early Triassic volcanic rocks from Quynh Nhai locality

\begin{tabular}{|c|c|c|c|c|c|c|c|c|c|c|c|c|c|c|c|}
\hline \multirow{2}{*}{ Site } & \multicolumn{2}{|c|}{ Location } & $\mathrm{Az} / \mathrm{Dp}$ & $\mathrm{n} / \mathrm{N}$ & \multicolumn{6}{|c|}{ ChRM } & \multicolumn{2}{|c|}{ VGP } & $\mathrm{dp}$ & $\mathrm{dm}$ & $\lambda_{\text {paleo }}$ \\
\hline & $\lambda\left({ }^{\circ} \mathrm{N}\right)$ & $\phi\left({ }^{\circ} \mathrm{E}\right)$ & (o) & & $\mathrm{Dg}$ & Ig & Ds & Is & $\alpha_{95}$ & $\mathrm{k}$ & $\lambda\left({ }^{\circ} \mathrm{N}\right)$ & $\phi\left({ }^{\circ} \mathrm{E}\right)$ & (o) & (o) & $\left({ }^{\circ} \mathrm{N}\right)$ \\
\hline QN01* & 21.524 & 103.733 & $198 / 60$ & $12 / 12$ & 229.6 & 4.6 & 244.6 & -44.1 & 6.6 & 44.0 & -31.3 & 355.8 & 5.2 & 8.3 & -25.8 \\
\hline QN02 & 21.680 & 103.616 & $198 / 60$ & $5 / 5$ & 65.3 & -58.5 & 40.8 & -6.9 & 12.1 & 41.0 & 42.9 & 220.9 & 6.1 & 12.2 & -3.5 \\
\hline QN03 & 21.680 & 103.616 & $198 / 60$ & $8 / 8$ & 66.1 & -61.5 & 39.1 & -9.4 & 14.7 & 15.1 & 43.5 & 223.5 & 7.5 & 14.9 & -4.7 \\
\hline QN04 & 21.680 & 103.616 & $198 / 60$ & $11 / 11$ & 83.2 & -40.6 & 61.7 & -2.8 & 6.9 & 44.4 & 25.6 & 206.3 & 3.5 & 6.9 & -1.4 \\
\hline QN05 & 21.680 & 103.616 & $198 / 60$ & $10 / 10$ & 79.4 & -44.9 & 56.5 & -3.4 & 4.2 & 135.8 & 30.1 & 209.1 & 2.1 & 4.2 & -1.7 \\
\hline QN06 & 21.680 & 103.616 & $198 / 60$ & $5 / 5$ & 100.7 & -48.9 & 61.2 & -17.8 & 3.3 & 533.7 & 22.6 & 214.1 & 1.8 & 3.4 & -9.1 \\
\hline QN07 & 21.680 & 103.616 & $198 / 60$ & $6 / 6$ & 101.7 & -47.0 & 63.2 & -17.1 & 5.2 & 164.2 & 21.0 & 218.8 & 2.8 & 5.4 & -8.8 \\
\hline QN7B & 21.680 & 103.616 & $198 / 60$ & $8 / 8$ & 102.1 & -48.7 & 61.8 & -18.4 & 5.0 & 122.6 & 21.9 & 214.1 & 2.7 & 5.2 & -9.5 \\
\hline QN08* & 21.665 & 103.628 & $198 / 60$ & $12 / 12$ & 339.1 & 54.6 & 235.2 & 52.9 & 10.2 & 19.2 & 13.8 & 238.8 & 9.7 & 14.0 & -33.5 \\
\hline QN09* & 21.669 & 103.633 & $212 / 44$ & $12 / 12$ & 171.0 & -62.1 & 72.5 & -61.7 & 2.0 & 454.8 & -2.7 & 239.3 & 2.4 & 3.2 & -42.9 \\
\hline QN10* & 21.669 & 103.633 & $212 / 44$ & 9/9 & 182.3 & -48.8 & 103.2 & -69.9 & 3.7 & 193.4 & -25.0 & 244.2 & 5.5 & 6.4 & -53.7 \\
\hline QN13 & 21.670 & 103.629 & $218 / 79$ & $6 / 6$ & 241.7 & -78.9 & 33.2 & -21.1 & 8.3 & 66.2 & 43.9 & 235.4 & 4.6 & 8.7 & -10.9 \\
\hline QN14 & 21.671 & 103.626 & $218 / 79$ & $14 / 14$ & 271.3 & 59.8 & 242.0 & -7.5 & 3.8 & 112.6 & 27.3 & 200.8 & 1.9 & 3.8 & 3.8 \\
\hline QN15 & 21.679 & 103.617 & $192 / 56$ & $9 / 9$ & 64.5 & -59.0 & 36.8 & -12.7 & 4.9 & 112.3 & 44.3 & 227.4 & 2.5 & 5.0 & -6.4 \\
\hline QN16 & 21.679 & 103.617 & $192 / 56$ & $10 / 10$ & 65.1 & -58.8 & 37.1 & -12.7 & 3.8 & 159.5 & 44.0 & 227.1 & 2.0 & 3.9 & -6.5 \\
\hline QN17 & 21.679 & 103.617 & $192 / 56$ & $13 / 13$ & 49.6 & -42.8 & 38.7 & 5.8 & 3.2 & 164.6 & 48.0 & 214.7 & 1.6 & 3.3 & 2.9 \\
\hline QN18 & 21.679 & 103.617 & $192 / 56$ & $7 / 7$ & 70.6 & -64.2 & 35.0 & -18.3 & 2.8 & 464.4 & 43.7 & 232.1 & 1.5 & 2.9 & -9.4 \\
\hline Mean $G$ & 21.678 & 103.618 & & $13 / 17$ & 79.6 & -57.5 & & & 9.5 & 20.2 & 5.5 & 52.6 & 10.1 & 13.8 & 38.1 \\
\hline Mean S & 21.678 & 103.618 & & $13 / 17$ & & & 48.3 & -10.0 & 8.0 & 27.7 & 35.7 & 217.4 & 4.1 & 8.1 & -5.1 \\
\hline
\end{tabular}

Note: $(*)$ - sites are excluded from the calculation of site mean; Az/Dp: Azimuth of dip/Dip; ChRM: characteristic remanent magnetization; VGP: Virtual geomagnetic pole; $\lambda_{\text {paleo }}$ : Paleolatitude of the site
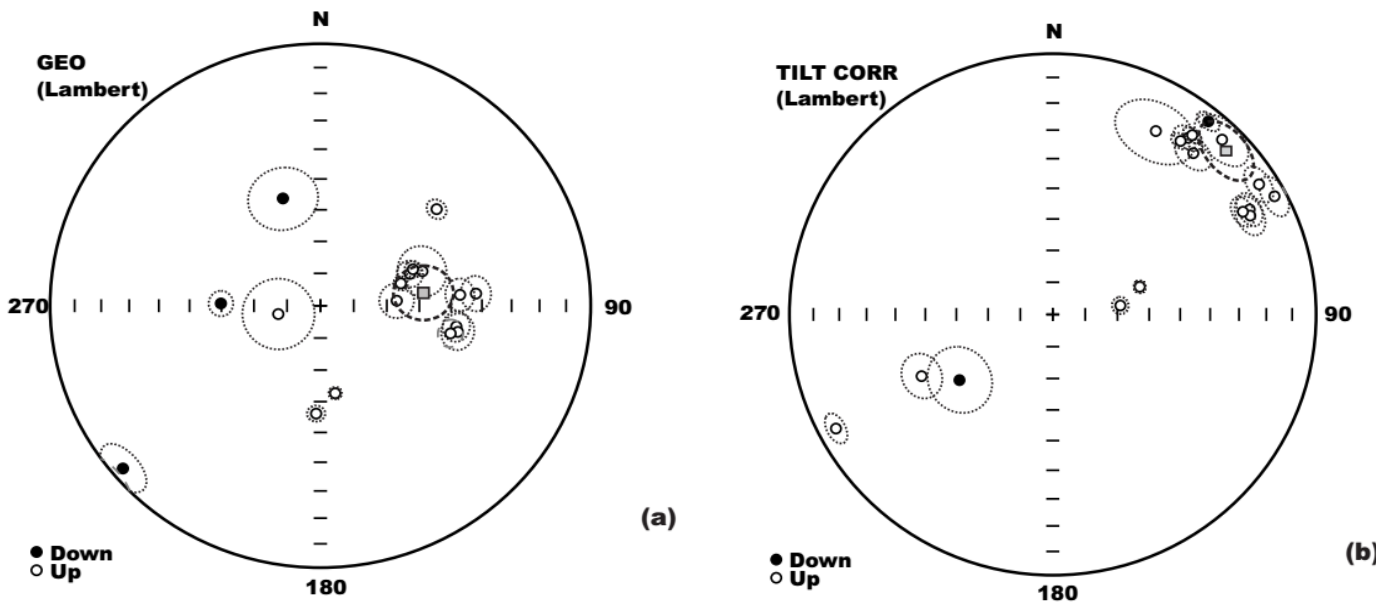

Figure 9. Lambert equal-area diagram showing the site mean directions with the ellipse of 95\% confidence. (a) in geographic coordinates; (b) in stratigraphic coordinates 
Vietnam Journal of Earth Sciences, 43(2), 220-235

Table 2. Late Permian - Early Triassic virtual geomagnetic poles from South China

\begin{tabular}{|c|c|c|c|c|c|c|c|}
\hline \multirow{2}{*}{ Age } & \multicolumn{2}{|c|}{ Locality } & \multicolumn{2}{|c|}{ VGP coord. } & \multirow[b]{2}{*}{$\mathrm{A}_{95}$} & \multirow{2}{*}{ Rock type } & \multirow{2}{*}{ Reference } \\
\hline & $\lambda$ & $\phi$ & $\lambda$ & $\phi$ & & & \\
\hline \multicolumn{8}{|c|}{ South China Block: } \\
\hline $\mathrm{P} 2$ & 29.6 & 103.4 & 52.7 & 252.1 & 6.0 & Basalt and red sandstone (Emeishan, Sichuan) & McEnhinny et al., 1981 \\
\hline $\mathrm{P} 2$ & 29.6 & 103.4 & 49.7 & 252.0 & 2.8 & Emeishan basalt & Zhao and Coe, 1989 \\
\hline $\mathrm{P} 2$ & 29.6 & 103.4 & 54.1 & 241.8 & 19.0 & Basalt and limestone (Emeishan, Sichuan) & Chan et al., 1984 \\
\hline $\mathrm{P} 2$ & 29.6 & 103.5 & 38.5 & 231.6 & 4.9 & Emeishan basalt, Xihekou & Liu et al., 1985 \\
\hline $\mathrm{P} 2$ & 28.1 & 102.9 & 58.9 & 246.1 & 6.6 & Basalt, Zhaojue, Sichuan & Liu et al., 1985 \\
\hline $\mathrm{P} 2$ & 27.6 & 101.9 & 63.5 & 264.3 & 9.8 & Basalt, Yanguan, Sichuan & Liu et al., 1985 \\
\hline $\mathrm{P} 2$ & 28.3 & 103.0 & 54.3 & 251.2 & 20.0 & Basalt, Meigou, Sichuan & Zhou et al., 1986 \\
\hline $\mathrm{P} 2$ & 26.8 & 101.8 & 25.6 & 216.4 & 12.6 & Basalt, Miyi, Sichuan & Zhou et al., 1986 \\
\hline $\mathrm{P} 2$ & 26.7 & 102.9 & 53.5 & 241.8 & 10.1 & Basalt, Huidong, Sichuan & Huang et al., 1986 \\
\hline $\mathrm{P} 2$ & 26.1 & 103.1 & 52.5 & 226.0 & 25.0 & Basalt, Dongchuan, Yunnan & Huang et al., 1986 \\
\hline $\mathrm{P} 2$ & 25.9 & 100.6 & 24.7 & 204.3 & 24.8 & Basalt, Binhchuan, Yunnan & Huang et al., 1986 \\
\hline $\mathrm{P} 2$ & 26.4 & 105.7 & 29.3 & 235.3 & 13.4 & Basalt, Xiongjiachang, Guizhou & Lin, 1984 \\
\hline $\mathrm{P} 2$ & 25.6 & 103.0 & 50.0 & 241.0 & 6.1 & Basalt, Kunming, Yunnan & Fang, Vander Voo, 1990 \\
\hline $\mathrm{P} 2$ & 26.5 & 101.8 & 23.6 & 210.3 & 9.1 & & Zhou et al., 1988 \\
\hline $\mathrm{P} 2$ & 26.5 & 101.8 & 28.9 & 218.2 & 6.4 & & Zhou et al., 1988 \\
\hline $\mathrm{P} 2$ & 28.3 & 103.0 & 57.0 & 277.1 & 12.7 & & Zhou et al., 1988 \\
\hline $\mathrm{P} 2$ & 28.3 & 103.0 & 47.1 & 231.0 & 19.0 & & Zhou et al., 1988 \\
\hline $\mathrm{P} 2$ & 29.6 & 103.4 & 54.1 & 241.8 & 19.5 & & Lung 1984 \\
\hline $\mathrm{P} 2$ & 29.6 & 103.4 & 51.2 & 232.5 & 2.9 & & Zhang 1984 \\
\hline $\mathrm{P} 2$ & 29.6 & 103.4 & 48.9 & 251.1 & 4.0 & & Zhao \& Coe 1987 \\
\hline $\mathrm{P} 2$ & 26.4 & 104.7 & 41.5 & 222.7 & 4.5 & & Huang, Opdyke, 1998 \\
\hline $\mathrm{P} 2$ & 30.1 & 102.7 & 51.7 & 254.1 & 5.1 & & Zhuang et al., 1989 \\
\hline $\mathrm{P} 2-\mathrm{T} 1$ & 32.4 & 105.5 & 47.2 & 226.3 & 4.2 & Red limestone, Guanyuan, Sichuan & Steiner et al., 1989 \\
\hline P2-T1 & 32.4 & 105.5 & 47.9 & 225.1 & 5.4 & Red limestone, Guanyuan, Sichuan & Heller et al., 1988 \\
\hline P2-T1 & 30.0 & 106.3 & 38.5 & 209.8 & 3.3 & Red limestone, Hechuan, Sichuan & Steiner et al., 1989 \\
\hline P2-T1 & 29.6 & 105.6 & 45.8 & 225.2 & 7.0 & Red limestone, Chongqing, Sichuan & Steiner et al., 1989 \\
\hline P2-T1 & 30.0 & 107.0 & 39.8 & 216.2 & 5.3 & Red limestone, Changshou, Sichuan & Enkin, 1990 \\
\hline P3-T1 & 29.5 & 106.0 & 40.7 & 215.0 & 6.8 & Sichuan & Enkin et al., 1992b \\
\hline P3-T1 & 32.4 & 105.5 & 50.3 & 222.9 & 3.3 & & Li et al., 1988 \\
\hline P3-T1 & 31.1 & 119.7 & 51.1 & 230.2 & - & & Li \&Wang, 1989 \\
\hline $\mathrm{T} 1$ & 31.3 & 110.6 & -40.3 & 37.3 & 26.3 & & Steiner et al., 1989 \\
\hline T1* & 29.2 & 117.3 & 55.4 & 354.1 & 2.1 & & Steiner et al., 1989 \\
\hline $\mathrm{T} 1$ & 28.6 & 106.9 & 46.3 & 219.3 & 11.0 & & Steiner et al., 1989 \\
\hline $\mathrm{T} 1 *$ & 30.1 & 102.7 & 71.0 & 276.7 & 4.6 & & \\
\hline $\mathrm{T} 1$ & 30.3 & 106.8 & 42.6 & 217.3 & 8.9 & & \\
\hline $\mathrm{T} 1$ & 28.0 & 105.5 & -44.0 & 37.4 & 6.8 & & \\
\hline T1 & 27.4 & 100.0 & 58.6 & 205.9 & 7.9 & & \\
\hline $\mathrm{T} 1$ & 31.2 & 110.5 & -40.4 & 37.0 & 26.3 & & \\
\hline $\mathrm{T} 1$ & 32.1 & 106.2 & 42.5 & 214.7 & 5.9 & & \\
\hline \multicolumn{3}{|c|}{ Mean of 37/39 poles: } & 47.5 & 228.9 & 4.6 & & \\
\hline
\end{tabular}

Note: (*) Poles are excluded from the calculation of mean pole 


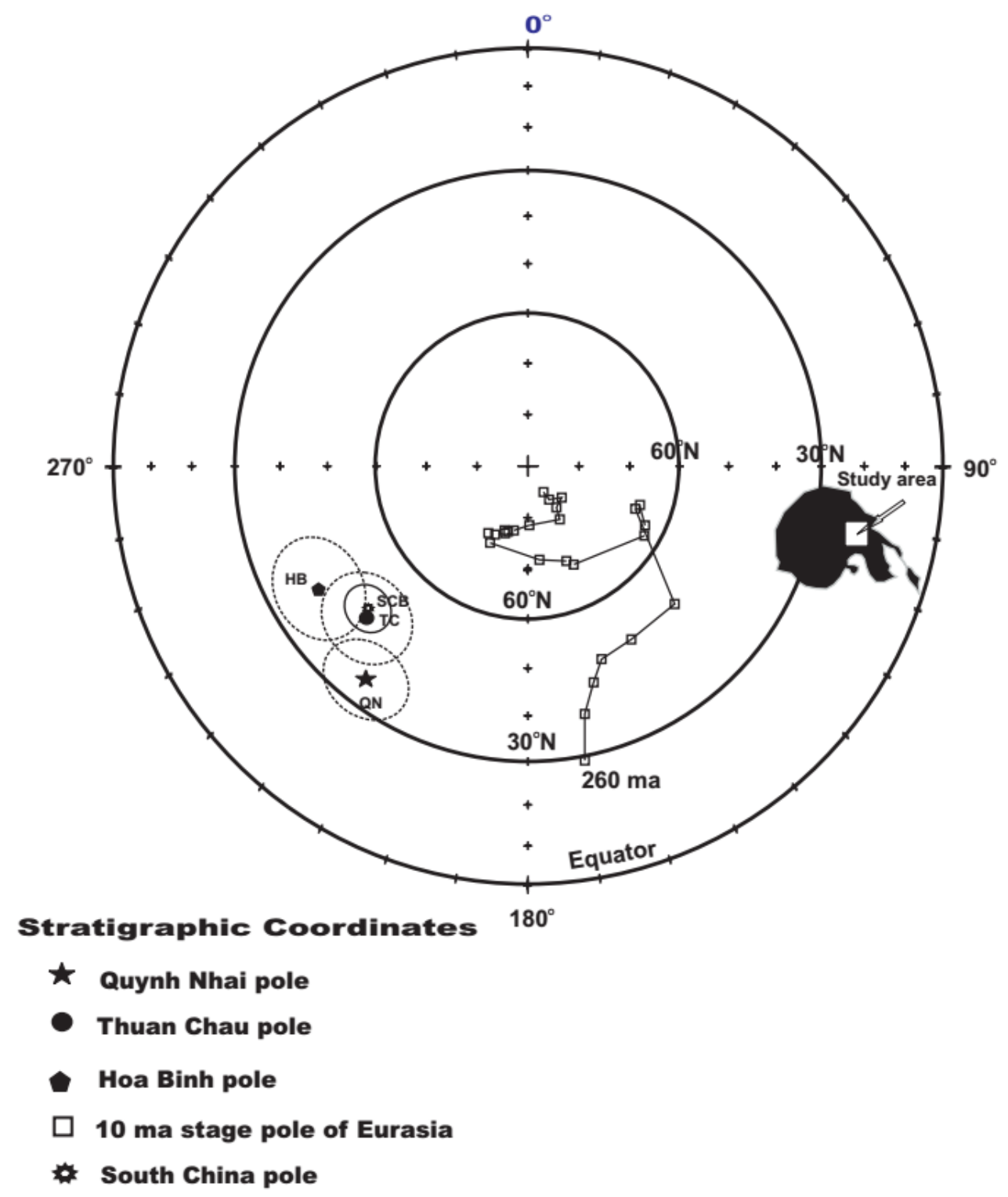

Figure 10. Equal-area diagram showing the positions of virtual geomagnetic poles (VGP) of Quynh Nhai locality relative to coeval paleopoles of Hoa Binh, Thuan Chau areas and the South China

Block, and the apparent polar wander path (APWP) of Eurasia after (Yang \& Besse, 2001)

\section{Discussions}

According to the paleogeographic reconstruction models, the northwestern Vietnam, in general, and the Quynh Nhai locality, in particular, belongs to the South China Block but not to the ancient Indochina Block as described by Metcalfe $(2011,2013)$ because the Song Ma Suture, the boundary between two blocks, situates to the southwest of this region. The rotation and latitudinal translation of Quynh Nhai locality relative to the South China Block are calculated and have the values as follow: $\mathrm{R}=14.7^{\circ} \pm 7.4^{\circ}$, $\mathrm{d}=-0.1^{\circ} \pm 7.4^{\circ}$ indicating that the Quynh Nhai 
locality has been relatively stable with respect to the South China Block, in terms of latitudinal position, since the Late Permian Early Triassic time, while has been undergoing a clockwise $(\mathrm{CW})$ rotation of $14.7^{\circ} \pm 7.4^{\circ}$ relative to the South China Block. The paleolatitude of Quynh Nhai basalts is consistent with that of Late Permian Thuan Chau basalts and Late Permian-Early Triassic Hoa Binh basalts reported by the authors in the other papers, while the observed declinations of Thuan Chau and Hoa Binh basalts showing no rotation of these areas relative to the South China Block, as well as the paleomagnetic results of Cretaceous redbeds from NW Vietnam (Cung et al., 2000; Takemoto et al., 2005) indicating that the observed CW rotation of Quynh Nhai locality might reflect a local rotation related to the folding process of these rocks.

The consistency of paleomagnetic information on relative tectonic displacement of the northwestern Vietnam region obtained from different rock formations with different geological ages shows that crustal elements of NW Vietnam have been close to, but not unequivocally a coherent part of the South China Block, since the Late Permian-Early Triassic. Development of the parallel NW-SE striking Song Ma and Song Chay orogenic belts did not involve the closure of wide $(>500 \mathrm{~km})$ ocean basins in this region.

\section{Conclusions}

The consistency of paleomagnetic results of basaltic rocks from northwestern Vietnam with the paleomagnetic data of Late Permian Emeishan basalt from South China indicates that these basaltic formations might have a similar origin and coeval age.

The Quynh Nhai locality, in particular, and the northwestern Vietnam region, in general, have been close to, but not unequivocally a coherent part of the South China Block and situated near the Equator since the Late Permian-Early Triassic.
Development of the parallel NW-SE striking Song Ma and Song Chay orogenic belts did not involve the closure of wide $(>$ $500 \mathrm{~km}$ ) ocean basins. The Red River fault has played a minor role during the Cenozoic India-Eurasia collision and there is insignificant displacement along this fault in terms of paleomagnetism.

\section{Acknowledgements}

This research has been supported by a grant for the basic research project (No.105.04-2011.24) from the National Foundation for Science and Technology Development (Nafosted) of Vietnam to Cung Thuong Chi. Part of Geissman's travel support and paleomagnetic measurements were provided by the University of Texas Stars Program.

\section{References}

Bai L.X., Wu H.N., Zhu R.X., 1997. Paleomagnetism of the Triassic Wangchang, Sichuan province, and its tectonic significance. Science in China (series D), 27(6), 514-518 (in Chinese)

Cai J.-X., Zhang K.J., 2009. A new model for the Indochina and South China collision during the Late Permian to the Middle Triassic. Tectonophysics, 467, 35-43.

Chan L.S., Wang C.Y., Wu X.Y., 1984. Paleomagnetic results from some Permian-Triassic rocks from southwestern China. Geophys. Res. Lett., 11(11), 1157-1160.

Chen H.S., Zhang Y.M., Xu S.W., Yan J.Z., Ding S.F., Zhou X.Q., Shi Y.Q., Jiang W.H., Xiao L., Wang H.S., 1999a. Lithosphere Structure Features and the Evaluation of Oil Resources of the Lesser Yangtze Area. Geological Publishing House, Beijing, 89-100 (in Chinese).

Cung Thuong Chi, Nguyen Trong Yem, Nguyen Quoc Cuong, 2000. Paleomagnetic study on Late JurassicCretaceous extrusive and intrusive rocks from northwestern Vietnam. Journal of Geology, A/256, 1-2, 1-8 (in Vietnamese).

Dercourt J., Ricou L.E., Vrielynck B. (Eds.), 1993. Atlas Tethys Palaeoenvironmental Maps Gauthier-Villars, Paris, 14(1), 307pp. 
Enkin R.J., 1990. Formation et deformation de 1'Asie depuis la fin de l'ere primaire: les apports de l'etude paleomagnetique des formations secondaires de Chine du Sud. Ph.D. Thesis, Univ. de Paris 7, 333pp.

Enkin R.J., Yang Z., Chen Y., Courtillot V., 1992b. Paleomagnetic constraints on the geodynamic history of the major blocks of China from the Permian to the present. J. Geophys. Res., 97(B10), 13,953-13,989.

Fang W., Van der Voo R., 1990, Paleomagnetism of the Late Permian Emeishan basalt, Yunnan, China. Eos Trans. AGU, 71, 488.

Fisher R.A., 1953. Dispersion on a sphere. Proc. Roy. Soc. London, Series A, 217, 295-305.

Gatinsky Y.G., C.S. Hutchinson, 1986. Cathaysia, Gondwanaland and the Palaeotethys in the evolution of continental Southeast Asia. Proceed. GeoSea V Congress, Geol. Soc. Malaysia Bull., 20.

Glotov A.I., Polyakov G.V., Hoa T.T., Balykin P.A., Akimtsev V.A., Krivenko A.P., Tolstykh N.D., Phuong N.T., Thanh H.H., Hung T.Q., Petrova T.E., 2001. The Ban Phuc Ni-Cu-PGE deposit related to the Phanerozoic komatiite-basalt association in the Song Da rift, northwestern Vietnam. Can. Mineral., $39,573-589$.

Hanski E., Walker R.J., Huhma H., Polyakov G.V., Balykin P.A., Tran Trong Hoa, Ngo Thi Phuong, 2004. Origin of the Permian-Triassic komatiites, northwestern Vietnam. Contributions to Mineralogy and Petrology, 147, 453-469.

Heller F., Lowrie W., li H., Wang J., 1988. Magnetostratigraphy of the Permo-Triassic boundary section at Shangsi (Guanggyuan, Sichuan, China). Earth Planet. Sci. Lett., 88, 348-356.

Huang K., Opdyke N., Kent D., Xu G., Tang R., 1986. Further paleomagnetic results from the Permian Emeishan basalts in SW China (in Chinese). Kexue Tongbao, 31, 1192-1201.

Huang K., Opdyke N.D., 1998. Magnetostratigraphic investigations on an Emeishan basalt section in western Guizhou province, China. Earth and Planetary Science Letters, 163, 1-14.

Huang K., Opdyke N.D., Kent D.V., Xu Guizhong, Tang Ruolong, 1986. New paleomagnetic results of
Permian Emeishan basalts. Chinese Science Bulletin, 2, 133-137 (in Chinese).

Hutchinson C.S., 1989. The palaeo-Tethyan realm and Indosinian orogenic system of Southeast Asia. In: Sengor, A.M.C. (Ed.). Tectonic Evolution of the Tethyan Region, Academic San Diego, California, 585-643.

Kirschvink J.L., 1980. The least-square line and plane and the analysis of paleomagnetic data. Geophys. J. R. Astron. Soc. London, 62, 699-718.

Lacassin R., Leloup P.H., Trinh P.T., Tapponnier P., 1998. Unconformity of red sandstones in north Vietnam: field evidence for Indosinian orogeny in northern Indochina? Terra Nova, 10, 106-111.

Lepvrier C., H. Maluski, Vu Van Tich, A. Leyreloup, Phan Truong Thi, Nguyen Van Vuong, 2004. The Early Triassic Indosinian orogeny in Vietnam (Truong Son Belt and Kontum Massif); implications for the geodynamic evolution of Indochina. Tectonophysics, 393, 87-118.

Lepvrier C., Nguyen Van Vuong, Henri Maluski, Phan Truong Thi, Tich Van Vu, 2008. Indosinian tectonics in Vietnam. C. R. Geoscience, 340, 94-111.

Li H.M., Wang J.D., 1989. Magneto stratigraphic features of the Permian/Triassic boundary profile of Meishan region, Changxing, Zhejiang Province. Science in China, series B, 6, 652-658 (in Chinese).

Li H.M., Wang J.D., Heller F., Lowrie W., 1988. Paleomagnetism of the Permian/Triassic boundary profile of Shangsi region, Guangyuan, Sichuan Province. Chinese Science Bulletin, 8, 612-615 (in Chinese).

Li Z.X., Powell C.McA., 2001. An outline of the palaeogeographic evolution of the Australian region since the beginning of the Neoproterozoic. Earth Science Reviews, 53, 237-277.

Li Z.X., Zhang I., Powell C.McA., Trench A., 1993. Palaeozoic global reconstructions, In: Long, J.A. (Ed.). Palaeozoic Vertebrate Biostratigraphy and Biogeography. Belhaven Press, London, 25-53.

Lin J.L., 1984. The apparent polar wonder paths for the North and South China blocks. Ph.D. Thesis, 248pp. Univ. of California, Santa Barbara. 
Liu B.J., Xu X.S., Pan X.Q., Huang H.Q., Xu Q., 1993 a. The Crust Evolution and Metallogenesis of Southern China Paleo-continental Deposition. Science Press, Beijing, 120-126 (in Chinese).

Liu C., Zhu R., Jing Z., 1985. Paleomagnetic study of Late Permian Emeishan basalts from Panxi and its neighbouring areas (in Chinese). In: Contributions to Panxi rift, China, edited by Y. Zhang, Geological Publishing House, Beijing, 2, 194-200.

Lung S.C., Wang C.Y.,Wu X.Y., 1984. Paleomagnetic results from some Permian-Triassic rocks from southwestern China. Geophysical Research Letters, 1(11), 1157-1160.

McElhinny M.W., 1981. Fragmentation of Asia in the Permian. Nature, 293, 212-216.

Metcalfe I., 1988. Origin and assembly of Southeast Asia continental terranes, Gondwana and Tethys, In: Audley-Charles, M.G., Hallam, A. (Eds.). Geological Society of London Special Publication, 37, 101-118.

Metcalfe I., 1991. Late Palaeozoic and Mesozoic palaeogeography of Southeast Asia. Palaeogeography, Palaeoclimatology, Palaeoecology, 87, 211-221.

Metcalfe I., 1996. Pre-Cretaceous evolution of SE Asian terranes. In: Hall, R., Blundell, D. (Eds.). Tectonic Evolution of Southeast Asia. Geological Society of London Special Publication, 106, 97-122.

Metcalfe I., 1998. Palaeozoic and Mesozoic geological evolution of the SE Asian region, multidisciplinary constraints and implications for biogeography. In: Hall, R., Holloway, J.D. (Eds.). Biogeography and Geological Evolution of SE Asia. Backhuys Publishers, Amsterdam, 25-41.

Metcalfe I., 2002. Permian tectonic framework and palaeogeography of SE Asia. Journal of Asian Earth Sciences, 20, 551-566.

Metcalfe I., 2011. Tectonic framework and Phanerozoic evolution of Sundaland. Gondwana Research, 19, 3-21.

Metcalfe I., 2013. Gondwana dispersion and Asian accretion: Tectonic and palaeogeographic evolution of eastern Tethys. Journal of Asian Earth Sciences, $66,1-33$.

Opdyke N.D., Huang K., Xu G., Zhang W.Y., Kent D.V., 1986. Paleomagnetic results from the Triassic of the Yangtze Platform. Journal of Geophysical Research, 91(B9), 9533-9568.

Phan $\mathrm{Cu}$ Tien, 1977. Late Permian-Early Triassic sediments from northwestern Vietnam. In: The geological problems of NW Vietnam region, Science and Technique Publisher House, Hanoi, 109-151 (in Vietnamese).

Polyakov G.V., Tran Trong Hoa, Akimtsev V.A., Balykin P.A., Ngo Thi Phuong, Hoang Huu Thanh, Tran Quoc Hung, Bui An Nien, Tolstykh N.D., Glotov A.I., Petrova T.E., Vu Van Van, 1999. Ore and geochemical specialization of Permo-Triassic ultramafic-mafic complexes in North Vietnam. Geologiya i Geofizika (Russian Geology and Geophysics), 40(10), 1474-1487.

Scotese C.R., Golonka J., 1992. Paleogeographic Atlas. Paleomap Progress Report 20-0692. Department of Geology, University of Texas at Arlington, 34pp.

Scotese C.R., Langford R.P., 1995. Pangea and the paleogeography of the Permian. In: Scholle, P.A., Peryt, T.M., Ulmer-Scholle, D.S. (Eds.). The Permian of northern Pangea. Paleogeography, Paleoclimate and Stratigraphy, Springer, Berlin, 1, 3-19.

Scotese C.R., McKerrow W.S., 1990. Revised world maps and introduction. In: McKerrow, W.S., Scotese, C.R. (Eds). Palaeozoic Palaeogeography and Biogeography. Geological Society Memoir, 12, 1-21.

Sengor A.M.C., 1979. Mid-Mesozoic closure of PermoTriassic Tethys and its implications. Nature, 279, 590-593.

Sengor A.M.C., 1984. The Cimmeride orogenic system and the tectonics of Eurasia. Geological Society of America Special Paper, 195, 82.

Sengor A.M.C., 1987. Tectonic subdivisions and evolution of Asia. Bulletin of the Technical University of Istanbul, 40, 355-435.

Sengor A.M.C., 1989. The Tethyside Orogenic System, an introduction, In: Sengor, A.M.C. (Ed.). Tectonic Evolution of the Tethyan Region. Kluwer, Dordrecht, 1-22.

Steiner M., Ogg J., Zhang Z., Sun S., 1989. The Late Permian-Early Triassic magnetic polarity time scale and plate motion of South China. J. Geophys Res., 94, 7343-7363. 
Takemoto K., Halim N., Otofuji Y., Tran Van Tri, Le Van De, Hada S., 2005. New paleomagnetic constraints on the extrusion of Indochina: Late Cretaceous results from the Song $\mathrm{Da}$ terrane, northern Vietnam. Earth. Planet. Sci. Lett., 229, 273-285.

Tran Trong Hoa, 1996. Magmatic activities of Northwestern Truong Son belt in MesozoicCenozoic. Material substances, forming conditions and mineral resource potential. Vietnam J. Earth Sci., 18(3), 218-227.

Tran Trong Hoa, 2001. Division and Comparison of Permian-Triassic basaltoid complex of the Song Da zone. Journal of Geology, A/265, 12-19, Hanoi, Vietnam (in Vietnamese).

Wu H.N., Zhu R.X., Bai L.X., Courtillot V., Yang G.L., Zhao Y.X., Xing J.X., 1999. Paleozoic and Mesozoic paleomagnetism of the Xingshan-Zigui profile of the Yangze block, Hubei Province. Science in China (series D), 29(2), 144-154 (in Chinese).

Yang Z.Y., Besse J., 2001. New Mesozoic apparent polar wander path for south China: tectonic consequences. Journal of Geophysical Research, 106(B5), 8493-8520.

Zhang K.J., Cai J.-X., Zhu J.-X., 2006. North China and South China collision: insights from analogue modeling. Journal of Geodynamics, 42, 38-51.

Zhang K.J., Cai J.-X., 2009. NE-SW-trending HepuHetai dextral shear zone in southern China: penetration of the Yunkai Promontory of South China into Indochina. Journal of Structural Geology, 31, 737-748.

Zhang Z.K., 1984. Sino-Korea and Yangze blocks were a part of Pacific paleocontinent in the Late Paleozoic. Bulletin of Chinese Academy of Geological Sciences, 9, 45-54 (in Chinese).

Zhao X.X., Coe R.S., 1987. Palaeomagnetic constraints on the collision and rotation of North and South China. Nature, 327, 141-144.

Zhou M.F., Arndt N.T., Malpas J., Wang C.Y., Kennedy A.K., 2008. Two magma series and associated ore deposit types in the Permian Emeishan large igneous province, SW China. Lithos, 103, 352-368.

Zhou Y., Lu L., Zheng B., 1986. Paleomagnetic polarity of the Permian Emeishan basalt in Sichuan (in Chinese). Geol. Rev., 32, 465-469.

Zhou Y.X., Lu L.Z., Zhang B.M., 1988. Preliminary paleomagnetic research for Panxi region. Collected Works for Panxi Rift. Beijing Geological Publishing House, 3, 212-230 (in Chinese with English abstract).

Zhu R.X., Yang Z.Y., Wu H.N., Ma X.H., Huang B.C., Meng Z.F., Fang D.J., 1998. Phanerozoic paleomagnetic pole wander curve and block movement of the Chinese main blocks. Science in China, series D, 28, 1-16 (in Chinese).

Zhuang Z.H., Jiang X.X., Pan Z.X., 1989. Paleomagnetism of the formation and development of Central Sichuan palaeo-upwarp. A Research Report, 1-87 (in Chinese).

Ziegler A.M., Gibbs M.T., Hulver M.L., 1998. A miniatlas of oceanic water masses in the Permian Period. Proceedings Royal Society of Victoria, 110, 323-343.

Ziegler A.M., Hulver M.L., Rowley D.B., 1997. Permian World Topography and Climate, In: Martinin, I.P. (Ed.). Late Glacial and Postglacial Environmental Changes. Oxford University Press, New York, 111-146.

Zijderveld J.D.A., 1967. A.C. demagnetization of rocks: Analysis of results, In: Methods in paleomagnetism, edited by D.W. Collinson, K.M. Creer, and S.K. Runcon, Elsevier, New York, 254-286.

Zonenshain L.P., Kuzmin M.I., Kononov M.V., 1985. Absolute reconstructions of the Palaeozoic oceans. Earth and Planetary Science Letters, 74, 103-116. 